\title{
JOHN PAUL II'S LEGACY AS A RESOURCE FOR FIGHTING TOTALITARIANISM: SLOVAK EXPERIENCE
}

\author{
Michal Valčo \\ Comenius University in Bratislava, Slovakia \\ Peter Šturák \\ University of Presov in Presov, Slovakia \\ Martina Pavlíková \\ Constantine the Philosopher University in Nitra, Slovakia \\ Gabriel Pal'a \\ University of Presov in Presov, Slovakia
}

\begin{abstract}
The monolithic vision of the cultural and civic life of communist totalitarianism is one of several actual strands of totalitarianism that the world has had to face in the past one hundred years. Central and Eastern Europe in general (along with many other countries around the globe) and Czechoslovakia, in particular, experienced the struggle with the Marxist totalitarian atheism and its consequences in the political, social, and moral (individual) lives of its citizens for four decades following WWII. This paper identifies and analyzes John Paul II's most important efforts to fight totalitarianism from his early years to his ministry as Roman Pontiff, shows ways in which his thoughts and actions inspired resistance in Czechoslovakia (e.g., the Charter 77 dissident movement or the Candle Demonstration of 1988), and suggests how his legacy may serve us today as we are confronted with old and new versions of totalitarianism, such as fascism, communism, hedonistic consumerism, nihilistic voluntarism, postmodern intellectual relativism (the ruling ideology in most Western academia), or religious fundamentalism. Instead of a violent revolution, whether political or religious, the late Pope seems to leave us with a message of courage to engage in a moral revolution while guarding the freedom of conscience as humankind's inalienable right.
\end{abstract}

\section{INTRODUCTION}

Central and Eastern Europe in general and Czechoslovakia, in particular, experienced the struggle with both versions of totalitarianism - German Nazism and 
domestic versions of fascism on the extreme right and the Marxist totalitarian atheism on the far left. Millions of people had to cope with the consequences of these different and yet so similar faces of unfreedom on the political, social, and moral (individual) levels for four decades following WWII. While Nazism/Fascism seemed for a long time to be a threat of the past, decisively rejected by intellectual elites and popular sentiments alike, the utopian dream of a classless society of peace and prosperity has somewhat been shunned reluctantly in public, while cherished by many in 'private saloons' of the universities and/or the mind of the hopeful. From among all post-communist countries in Central and Eastern Europe, Poland has been the only state that has decidedly condemned the communist past along with its ideology and symbols that represent it. Criticized and ridiculed by many in the West and viewed by uneasiness and apprehension by some in the Central and Eastern Europe, this uncompromising stance is actually entirely legitimate. It was not a poor implementation of an otherwise "wonderful idea" that caused the death of over 100 million people worldwide. Communists worldwide implemented the main doctrines of the ideology - permanent class struggle; violent revolution; the dictatorship of the 'proletariat' - doctrines such as these have caused millions of dead, impoverished, or displaced people and stood behind devastated economies, cultures, and minds.

Marxism worked its unprecedented evils in the name of a promised posttheistic redemption, and it was this fanatical, messianic self-understanding of Marxism, like the one ideology which holds the redemptive' key to the riddle of history,' that made communists largely imperceptive of their own sins. Hence to live and survive with dignity under such conditions required every possible resource that could uphold decency, human mutuality, and human dignity (Kardis 2019, 150). What remained noble in both the sacral and secular cultures joined hands, despite great dangers and sacrifices, to fight this totalitarianism - and Christians of all backgrounds were more often than not at the forefront of the struggle. One of the leading European voices that spoke and acted against the totalitarian power of communist dictatorship was the Polish theologian, church representative, and intellectual, Karol Wojtyła [1920-2005], who became known to the world as Pope John Paul II.

Therefore, the goal of our contribution is to explore in what ways can the rich legacy of John Paul II serves as a resource for fighting totalitarianism today. We will offer a concise description of the Nazi and Communist ideologies and show their surprising resemblance. We will also attempt to understand and evaluate the failure of Marxism, the ideology underlying the communist dictatorial rule in our part of the world, from the perspective of a Christian theological critique of modern Marxist atheism as a distinct Christian heresy. Moreover, we will offer a short analysis of the effects of this 'political religion' on the Church and society in Slovakia. The paper will start by recapitulating the experiences of Czechoslovakia (though the focus will be more on Slovakia) with the totalitarian ideologies of Nazism and Communism in the 20th century. In the second part, we will briefly analyze our current struggles with old and new forms of totalitarianism, focusing mainly on the totalitarianism of consumerism, the insidious menace of the Western culture. Then, in the last part, we will introduce selected emphases from John Paul II, which, we want to propose, constitute a significant part of his legacy in fighting totalitarianism today. 


\section{NAZISM AND COMMUNISM: TWO SIMILAR FORMS OF TOTALITARIANISM}

\section{Ideology of Nazism}

Due to its adoration of the power to dominate and its emphasis on the connection between "blood" and the "soil" (nationalistic principle based on racism), Nazism can be described as a renewal of paganism in traditionally Christian European culture (Tavilla, Kralik, Webb, Jiang, and Aguilar 2019). It is a coherent system, a worldview that uses racial chauvinism, social Darwinism, and nihilistic existentialism to create the idea of a superhuman - the 'Übermensch.' There has been competition by the human race in the history of the world to gain adequate 'Lebensraum' - (living space). In this struggle, wars are the necessary and inevitable mediators of 'progress' understood in terms of social evolution based on the advancement of one particular race over against other, inferior races. Wars are inevitable because the will and ability of one dominant race to rule and subdue other (inferior) races will logically and inevitably develop, causing armed conflict with the neighboring nations.

A person's identity under this neo-pagan ideology is an illusion until he finds identity in a nation ('Volk'). This "nation," comprised of individuals of "pure," that is, German blood is the new "god" to whom much must be sacrificed. Individual human rights are illusory or even dangerous, whereas propaganda and manipulation of the masses are useful tools in promoting the well-being of a nation/race. A summary of Gene Edward Veith's well-written book Modern Fascism: Liquidating the Judeo Christian Worldview (1993) could be presented in the following points: If the term 'human person' is an illusion, everyone had better find their identity in a 'Volksstaat' (people state); if society creates an individual then let it be and let all the respect toward human rights be substituted by propaganda; let it manipulate humans and make them into what we (the government) want. If it is power alone that stands behind all of the institutions, let us take this power. If there is no overarching truth valid for all people, if the race is the determining value, let us evaluate all of the ideas in the light of the racial interests and usefulness; if societies are in essence racial (racially-based), let us be racists and let us try to rule over other races and people (Valčo 2016, 118; Veith 1993).

The roots of fascism reach all the way down to the modern doctrine of the sovereign self, i.e., to the Cartesian project of the modern era, culminating in the European Enlightenment, that framed into antipoles the thinking subject of man and the surrounding material world (Kardis et al. 2019, 114-115). This 'dualistic' way of thinking gave rise to a Western political economy, which, despite its technological advances, failed to cope with the critical human problem: the sinful greed of the human heart (concupiscentia). The modern convergence of technological progress and economic well-being entails in the context of this greedy disposition of the human heart the stench of nihilism. It was precisely in the trenches and the death camps of the war where we could witness most blatantly "the descent of the modern sovereign self into the dark night of postmodern nihilism" (Hinlicky 2016, 82). 


\section{The Nazi Oppression and Fascism in Slovakia, 1939-45}

The German Nazis did not rule in Slovakia directly, as opposed to in the socalled 'Czech Protectorate,' which they annexed to the 'Dritte Reich' [The Third Empire]. Hence the racial emphasis was less prominent in the Slovak sociopolitical discourse. Fascism in Slovakia had a strong religious overtone; thus, numerous scholars label the regime as a 'clero-fascist' regime (Magdolen 2005; Vasil'ková - Androvičová 2018; Hudek 2013). In the case of the fascist Slovak State, the state's symbolic and legal privileging of Christian actors, particularly the Catholic Church, and the integration of this Church into the symbolic character of the state, became evident between 1938 - 1945.

The representatives of the Catholic Church became important actors of political and public debates. In addition, the Catholic Church became a hegemonic leader in establishing the basic principles of regulation and functioning of religious and educational life in Slovakia, to the disadvantage of other religious groups (namely Protestants and Jews).

In October of 1938, Slovakia, in the person and office of its president, Dr. Jozef Tiso, a Catholic priest, adopted some of the controversial rhetoric of the Nazi propaganda and tried to influence the teaching and practice of the Slovak churches to comply with the principles of the 'Dritte Reich' ideology. Though there were those who resisted and showed courage and willingness to sacrifice for the truth, most people were too weak and/or too fearful to react until it was too late. Tiso signed an agreement with Hitler, according to which the "German empire takes over the defense of political autonomy and territorial integrity of Slovak republic" (Mannová 2003, 284). Slovakia had to promise a "compliance of its foreign policy" with Germany, including a military alliance. This included the infamous deportations of the Jews to concentration camps. At least 70 out of 90 thousand Jews were deported from Slovakia in 1942-45. A vast majority of them never came back (Mannová 2003, 288-290; Valčo 2012, 217-218).

Most of the leadership, clergy, and laity of the established Roman Catholic Church accepted the clerical-fascist regime as a 'smaller evil' compared to direct occupation by the Nazis. This proved to be rather fatal, however. The ensuing atrocities of dehumanization and death in the concentration camps that the Slovak regime became part of in its alliance with Germany revealed this 'smaller evil' in its proper light as plain EVIL at its worst. Such a morally relativistic position led to a historically unprecedented genocide of the Jews, Gypsies, Slavs, and domestic political opponents in the concentration camps of the "Dritte Reich."

It is important to include this painful outline of historical events and decisions made by the church establishment of the first Slovak Republic to contrast it to the stance of the Polish Catholic Church of the time. Though heroes and traitors appeared in both contexts, and numerous cases of heroic, sacrificial help by the Slovak Catholic priests to the Jews were documented, the overall attitude of the Polish Catholic Church to the Nazi ideology during WWII could be described as a clandestine revolt. Young Karol Wojtyła himself participated in hiding persecuted persons and obtaining and helping them obtain false IDs to save them from imprisonment and death. 


\section{The ideology of Communism (Applied Marxism): Communism as a Christian Heresy}

The danger from the 'extreme right' as represented by the Nazis and the Fascists in the 1930s and 40s was followed by its 'extreme left' alternative, which has since appeared to be even more attractive and, therefore, is intellectually legitimized by the academia (Geuss 2008; Blackledge 2012). To many intellectuals (including religious intellectuals) today, as it was back in the 1940s in Europe, Marxism continues to be a desirable secular version of the Bible-proclaimed Kingdom of God, in which the politically emancipated and the new ideologyliberated humanity assumes God's place, and in which salvation consists exclusively of the immanent dimension (Valčo 2016, 119).

In fact, we can observe acute resemblances between Marxism and Christianity, thus perceiving Marxism as a 'Christian heresy' (Valčo 2013, 298-299). The Marxist' homo faber' is called to conquer nature and create a new reality of the world, much like the Christian image of humans being created as God's covenant partners to beautify and govern over the creation. The fall into sin is replaced in Marxism by the alienation effected by the division of labor; ruthless critique of religions and philosophies replaces the Christian prophetic struggle against the idols and sin; the hope of the coming messianic figure is replaced by the anticipation of the liberating proletariat. International' class consciousness' in Marxism has a ready parallel in the global vision of evangelization based on Mt 28:18-20. The dogmas of the Church are replaced by 'scientific laws' and ideological dogmas of the Party and much like the infallibility (in matters of the faith) of the Roman Pontiff, so also the Communist politburo's ideology is beyond questioning and doubt. Repentance of sin is replaced by overcoming one's false consciousness. "In general ... Marxism follows Christianity step by step in the meta-narrative of creation, fall, redemption, and final salvation ... yet without God or the Kingdom of God," as Hinlicky rightly observed (Hinlicky 2010, 326-327). In fact, already in 1968, the distinguished moral philosopher Alisdair MacIntyre published an incisive analysis in which he argued that "only one secular doctrine retains the scope of traditional religion in offering an interpretation of human existence by means of which men may situate themselves in the world and direct their actions to ends which transcend those offered by their immediate situation: Marxism." MacIntyre substantiates his claim by pointing out that Marxism is potentially the only human ideology that "shares in good measure both the content and the functions of Christianity as an interpretation of human existence, and it does so because it is the historical successor of Christianity" (MacIntyre 1984, 2).

According to this holistic, comprehensive interpretation of reality (i.e., a secular historical meta-narrative), the class struggle is the all-pervading dynamic of human history. Revolution is the unavoidable means of attaining a 'classless society' where the alienation of man on a social, material, and existential basis is overcome. In scientific Marxism (as begun with the mature Marx himself), the story of cataclysmic historical development through class conflict culminating in the dramatic collapse of capitalism acquires the status of a 'law of history' (Valčo 2016, 119). As indicated above, the story is today called a 'meta-narrative,' that is, a grand 
construction that tells of the fall of the human species from a prehistoric state of the primitive, tribal cooperative into the division of labor.

The division of labor in capitalism causes humans to lose a grip on their own essence as intentional social producers and lose a capacity to direct activities, initiate historical processes, indeed, create their own lives. A violent revolution that will bring about the redistribution of wealth through nationalization of most private property, and the consequent dictatorship of the proletariat (which in reality turned out to be the despicable terror of a ruling communist politburo as helped by secret police) will achieve the goal of a just, classless society. Taking history into their own hands, the revolutionaries regain their misappropriated possessions and create their own destinies (Valčo 2013, 296-297). Thus, according to the ethics of the 'revolutionary praxis,' the success of the revolution becomes the highest good for the Marxists.

There is a direct connection between Marxist atheist ideology - promoted as a secular religion with a corresponding religious zeal - and the loss of civic virtue in the communist 'homo Faber' social anthropology, with its unimaginable acts of cruelty (Hinlicky 2010, 315-316). 'Coercive atheization' thus becomes mandatory. In order to build a kingdom of righteousness on earth, it is necessary to root out from the mind of humanity the illusory hope of a kingdom of bliss in heaven above. The metaphysical posit that "man is the highest being for man" is no epiphenomenon, as Paul Hinlicky rightly argues, but really the act of "initial faith out of which Marxist rationality proceeds... Marxism made people uncommonly cruel and selfish and committed enormous, monstrous crimes because of a moral illusion peculiar to it: its consequent, systematic atheism. It was precisely as a promise of post-theistic redemption that Marxism worked its unprecedented evils" (Hinlicky 2010, 316).

\section{The Communist Rule in (Czecho)Slovakia, 1948-1989}

After World War II, the official policy of the Communist parties taking power in Eastern and Central Europe was to suppress any religious presence by imposing severe restrictions on churches and other religious institutions. The situation in Czechoslovakia, too, radically changed after the Communists came to power in February 1948. ${ }^{1}$

The Communist politburo in Czechoslovakia despised the Christian churches because they opposed revolution as the inevitable outcome of class struggle. Christianity in Slovakia had the allegiance of many people and thus became a rival to the Communist attempts at total control of the society. Religion was thus defined as the opium of the people and a popular superstition (Marx 2000). It was reluctantly tolerated as an insignificant 'private delusion' without any real influence on culture and politics (Konstantinov 1973, 398). The government authorities worked to ensure that the Church would lose its independence and its social, political, and moral influence in society by virtue of the legal decree Nr. 218/1949Zb., all pastors were forced to become state employees (Jozefčiaková 2003, 101). They could conduct worship services and burials, but anything else put them at risk of grave danger. They were not even allowed to meet outside of their deaneries. All of the orphanages, church schools, retirement homes, homeless shelters, etc., as well as most church 
properties, were confiscated (Valčo 2012, 221-222). The Communist government imposed these extreme measures by means of state laws from 1949-1950. Thus, all of the churches were humbled and subdued under the 'patronage' of the state, which meant a verdict of a slow death! In every country, police and secret service were used to blackmail, brainwash, and coerce political/religious opponents (Letz 2007). There was all-pervasive propaganda by the state-run mass media. People who were considered potentially dangerous to the regime were often deported to gulags in Siberia - in fact, more than 7400 deported persons were from former Czechoslovakia.

Two grand, comprehensive, and yet utterly fatal ideological narratives ruled the Slovak society with a ruthless claim on total compliance of the people in 19391989 - Fascism and Communism. They both relied on ideological education, which we should rather call indoctrination by means of propaganda manipulation. They both perceived Christian religion as unwelcome competition, thus an enemy of the state, and yet, they learned from religion and adopted from it its rituals, projecting their own' belief systems' based on carefully fabricated and constantly reinforced myths (such as the alleged invincibility of the Red Army (Markwick 2002). Both ideologies were surviving in a constant state of war against real and imaginary enemies, blaming their own failures on these enemies and/or justifying their austere measures (e.g., the curtailing of individual freedoms) against often mere imaginary counterrevolutionaries. Both of these modern '(meta)narratives' brought about countless victims, and both of them continue to confront us in new, insidious forms today (Žalec 2013). Karol Wojtyła had to deal with both of them during his life and ministry. Nevertheless, it was arguably the communist ideology, that in the decades following WWII presented itself as a continuous, ominous threat to freedom and dignity. As a young priest, then a bishop, archbishop, and finally Pope John Paul II had to struggle with, survive under, and inspire people to confront its totalitarian claims courageously.

\section{CONTINUING THREATS OF TOTALITARIANISM: OLD AND NEW FORMS}

As mentioned above, many of the challenges related to the individual and social living of humans in the modern era can be traced back to the proud modern doctrine of the sovereign self and to the accompanying conviction that human rational faculty is capable of disinterested, objective evaluations, rational moral judgments and, therefore, able to construct a new, demythologized, scientific world of peace and prosperity. Each of the three socio-economic and political visions of reality that followed and built upon the Enlightenment-Marxism, Fascism, and democratic Capitalism - propagated their own narratives of reality that aspired to attain the level of an overarching meta-story. Each of them brought a certain level of order and promised to usher a kingdom of heaven on earth to its adherents, and each of them morphed into a twisted version of totalitarianism (though more tacitly, in the case of the latter). Humanity's hope for secular salvation, however, died in the trenches of the two world wars; was shattered in the Siberian gulags; was seriously wounded in the stock market crashes of the 1930s and more recently in the socio- 
economic crises that followed the real estate bubble burst in 2008 (and many times in between). Thus, in place of a normative meta-narrative, many in the Western world adopted a hermeneutic of suspicion with regard to big narratives - political, cultural, religious, or even scientific, though human hopes in science seem to be somewhat resurgent today. The world, as we perceive it in the postmodern West, no longer seems to have a narratable character (Valčo 2015a, 271).

The situation of post-totalitarian European societies has its own complexities and context-induced challenges. A lack of democratic experience along with the poorly managed transformation process of a state-subsidized economy to a market economy and the omnipresent cancer of corruption give rise to feelings of disenchantment with the new democratic system (Tismaneanu 2009). It appears to inadvertently point us to questions about liberal capitalist democracy, as this sociopolitical system aspires to be the natural and only viable alternative to neo-fascist and neo-Marxian tyrannies.

A liberal capitalist democracy may indeed embody the best socio-economic system and human political governance, provided some crucial conditions are met. At the same time, this celebrated 'socio-political contract' moves dangerously close to the abyss of the next totalitarianism, stemming from unchecked consumerism and media manipulation (Muzykant, Ponomarenko, Barabash, Denisenko, and Shlykova 2019). A growing number of contemporary analysts (Giddens 1998; Harvey 2010; Touraine 2001) point out that global media corporations have a great deal of control over what goods, news, and information people have access to. These corporations spend vast amounts of money to figure out what buzzwords and cultural mirages their target audiences will respond to. Though unarticulated, their goal is clear: to be more efficient in marketing whatever it is they (the new political aristocracy, social engineers, and/or economic oligarchs) wish to sell - products, services, values, or general outlooks (Valčo 2015b, 129-130). In place of a state-directed, planned economy and political monopoly of one party, people now suffer under a more clandestine form of totalitarianism - the 'soft' totalitarianism of consumerism. A general sense of uneasiness seems to be more than ever justified by what appears to be unchecked atomization of our social, economic, and cultural realities. $^{2}$

The critical question that lingers in the air is whether the current liberal capitalist democracies (i.e., liberal democratic governance) takes the power of culture and religion seriously as major driving forces motivating the wills and the hearts of individuals and communities (for better or worse)? Or should we rather self-critically admit that our Western societies' regard for and cultivation of liberal capitalism exhibits signs of self-indulgence, a certain measure of arbitrariness in its criteria and goals, and a dangerous disregard of culture and religion when it comes to their constitutive agency in cultivating and sustaining the very value system of liberal capitalism and democracy $?^{3}$ As the late member of the Federal Constitutional Court in Germany (1983-1996), Ernst-Wolfgang Böckenförde (1991) stated in his famous dictum (originally from 1976): "The liberal, secularized state is nourished by presuppositions that it cannot itself guarantee" (Böckenförde 1991, 45).

The danger of social and moral entropy threatens, above all, the marginalized, disadvantaged, and socially excluded. However, even the economically and socially 
'successful' individuals, still constituting a critical majority in most of the developed European economies, are also affected. "They face the dangers of 'flattening' and manipulation. Human individuality and personhood seem to be lulled by the omnipresent slogans of freedom, especially in its economic and moral senses, only to be consumed and 'flattened' by the 'soft' totalitarian power of consumerism." (Valčo 2015a, 135) The loss of authentic personhood goes unnoticed in this process, as humans are being subconsciously influenced by the omnipresent normative images and messages of economic, political, and cultural marketing ads and media content (Wacquant and Roulleau-Berger 2003, 77). Paradoxically, people are invited to celebrate their freedom of choice, ridden of the burdensome task of a true selfreflection. They are to devote their time and energy to solving 'practical issues' at hand and shy away from the 'impractical issues' of spiritual integrity and deep moral responsibilities.

These seemingly less tangible realities become less and less intelligible and increasingly perplexing, as individuals lose grip with the inner core of their being (their 'authentic selves') (Martin - Rojas - Kralik 2020, 44-45), which urges them, even more, to flee into the more 'intelligible' and 'real' world of economic choices and instantly available gratifications. Thus the vicious circle of economic realities intertwined with insatiable human desires and unquenchable fears closes in upon us (Valčo 2015a, 135). Devoid of its proper cultural and religious roots and context left to be governed solely by its own regulative principle - the invisible hand of the market and through it, the invisible but very much real force of human greed and desire to dominate, expose the heretical, pseudo-religious essence of certain forms of liberal capitalist democracy (Piry 2019). Loïc Wacquant $(2003,411)$ expressed it eloquently when he talked about how "[ $\mathrm{t}]$ he invisible hand of the market and the iron fist of the state combine and complement each other to make the lower classes accept desocialized wage labor," and warned about "the social instability it brings in its wake." Wacquant $(2003,411)$ hence revealed the sad paradox that "[a]fter a long eclipse, the prison thus returns to the frontline of institutions entrusted with maintaining the social order."

\section{JOHN PAUL II AS A RESOURCE OF FIGHTING TOTALITARIANISM TODAY}

The mix of old and new forms of totalitarianism (and we have mentioned but a small sample) that simmers beneath the surface of our awareness and re-emerges with ever-surprising potency when we least expect it real. It is what we are facing today in Slovakia, in Central and Eastern Europe, in fact in Europe and around the globe. What follows below are short probes from the historical experiences with John Paul II as a person, which will illustrate how this exceptional man can be a resource in our struggle with various types of totalitarianism today.

Already when he was young, Karol Wojtyła loved to hike in the High Tatra mountains in northern Slovakia. He made frequent visits there as a tourist, hiking with a small group of friends, and meeting young people from Slovakia. The Czech Republic and Slovakia use languages that are similar enough to the Polish language 
that people can understand each other. This natural, linguistic, as well as the historical affinity of our nations, and the fact that Slovakia has been predominantly Roman Catholic, meant that the Poles and the Slovaks communicated and shared ideas and resources even during the difficult totalitarian era. Our clergy and laity paid attention to any news that they could get on the Polish resistance, especially after 1950. Literature was being smuggled across the border, and secret activities were organized by both sides.

In times of crisis, people need examples of courage and faithfulness. Wojtyła's example soon became known in Czechoslovakia. This man who began courses in the clandestine underground seminary run by the Archbishop of Kraków, Adam Stefan Cardinal Sapieha during the Nazi occupation and who did not hesitate to stand his ground as a priest and later bishop (when he was only 38) of Krakow and cardinal against the oppressive regime - this man became an inspiration for many in and outside of Poland.

Many, though not all, political dissenters in Czechoslovakia were active Catholics. Likewise, there were important religious intellectuals among the signatories of the Charter 77 document, a public memorandum protesting against the violations of human rights in Czechoslovakia. Most of them suffered severe consequences of their actions; some were even imprisoned. Yet, a decade later, in 1988, the famous Candle Demonstration, comprised mostly of Catholic believers, took place in Bratislava. Though dispersed by the brutal police force, it became a foreshadow of major changes to come. Fear was in the air, but so was determination and resolve. Few would have believed at that time (i.e., in 1988) that the same police personnel and secret police agents who used water cannons, tear gas, and clubs to terrorize the protesters would merely a year later take a much more reserved, cautious approach. Though not without some isolated incidences of violence, the socalled 'Velvet Revolution,' the hallmark of peaceful change of the political regime in Czechoslovakia, surprised the outside world as well as the natives with a bloodless transfer of power facilitated by the first free elections in 1990. However, none of this would have happened had it not been for the courage and perseverance of the dissidents and the undying hope of those who could hold on to vestiges of faith in a sea of cynicism and raw power. Despite the seemingly impenetrable Iron Curtain that divided Europe during the Cold War, the voice of the Polish Pope was heard in Czechoslovakia prior to 1989. After the elections of 1990, his message was heeded by many inside and outside of the bounds of the Church.

\section{John Paul II against Communism}

Courage and perseverance in the face of evil seemed to have been the key to its downfall. However, the courage to withstand oppression and act on behalf of those who are oppressed was not easily cultivated in an atmosphere of suspicion and fear. Christians in the 'Eastern bloc' (the Communist part of Europe) were deliberately isolated, prevented from international travel, and deprived of information and foreign literature. Isolated and underinformed, the existing groups of the faithful were surviving underground, but they did not dare to start organizing publicly. Things began to change when Wojtyła became the Pope in 1978, especially when he 
paid his first visit to Poland, his homeland. Millions poured out into the streets in open defiance of the regime. One of the most important sentences that they heard from John Paul II was: "Do not be afraid!" "Be not afraid" became his rallying cry, which became obvious following his 1979 address to the UN General Assembly. Church's struggle against totalitarian atheism thus received a new champion. As if he wished to say: look at your brother, sister, your neighbor; look how many of you have come out into the streets! You are not alone!

The Soviet leaders predicted that he could be trouble. Mikhail Gorbachev acknowledged that without John Paul II's influence, the collapse of communist governments would not have been thinkable. Gorbachev wrote these words in 1992: "Everything that happened in Eastern Europe in these last years would have been impossible without the presence of this pope and without the important role including the political role — that he played on the world stage" (Aikman 2003, 258; Tierney 2017, 290).

Without John Paul II, there would be no Solidarnosc ${ }^{4}$ (September 1980), and without the movement of Solidarnosc, it would hardly have come to the sociopolitical tensions and subsequent changes that we witnessed in the 1980s. Proclaiming freedom of conscience as mankind's "inalienable right," Pope John Paul II helped bring down totalitarianism in Central and Eastern Europe.

As the archbishop of Krakow, Karol Wojtyła expressed his clear antitotalitarian stance as one of the main supporters of the Dignitas Humanae document of the Second Vatican Council, arguably Church's foundational declaration on religious freedom in the $20^{\text {th }}$ century. Along with numerous other supporters of the document, Wojtyła maintained that "the right to religious freedom has its foundation in the very dignity of the human person, as this dignity is known through the revealed word of God and by reason itself" (Pope Paul VI 1965). During the turbulent 1970s in Poland, Wojtyła continued to champion human rights and spoke on behalf of the human dignity of all Poles, regardless of their social status. After he became Pope John Paul II in October 1978, Wojtyła recalibrated Pope Paul VI's 'East Policy' (i.e., policies dealing with the communist countries in Eastern Europe, the Soviet Union, etc.). He was more resolute in pressing for communist regimes to comply with international agreements on human rights while keeping the communication channels open with the communist leaders. His influence became so unsettling to the leaders of the Soviet bloc that an assassination attempt was organized in 1981, which was most likely sponsored by the Soviet KGB (though this was never officially proven). John Paul II recovered from the wounds inflicted by the Turkish assassin and visited his homeland again in 1983, a year during which martial law had been imposed on Poland in attempt to suppress the rising tide of freedom. The Pope met with General Wojciech Jaruzelski, the communist leader of Poland at that time, and emphasized the need for openness and social justice for all. He met with the imprisoned leader of Solidarity, Lech Walesa, and other leaders of the Polish dissent. Martial law was lifted within one month of Pope's visit, which marked another remarkable achievement of John Paul II's papacy. The Pope then continued to encourage his people via live radio broadcasts from the Vatican. These reached his fellow countrymen on a weekly basis, giving them courage and strengthening their will to persevere. Pope's campaign against communist totalitarianism culminated in 1989 
when the Polish government, as the first within the Eastern bloc, agreed to roundtable discussions with the opposition leaders (representatives of Solidarnosc) and the Catholic Church. The time was ripe for such negotiations, as Mikhail Gorbachev, the Soviet leader at the time, had since 1986 announced the 'Glasnost' principle as part of his 'Perestroika' attempts to reform the communist political regime in his country. The free elections that followed in June 1989, first after decades of oppression, led to the formation of a new Polish government led by a noncommunist prime minister. A shockwave of these events was felt throughout Europe as people in the Eastern bloc started to notice the emergence of a new political atmosphere, one that more conducive to political reforms and freedom. Only a few months later, the Berlin Wall was torn down. Czechoslovakia had its 'Velvet Revolution', and other countries followed suit as well. The tidal wave of freedom did not stop at the border of the Soviet Union but swept across it through the emancipation struggles of numerous nations within the USSR. Finally, the USSR dissolved in 1991, the same year when Soviet occupation troops finally left Czechoslovakia.

\section{LESSONS TO BE LEARNED: JOHN PAUL II AS A RESOURCE AGAINST TOTALITARIANISM TODAY}

What follows is a summary of ten inspiring lessons that we can learn from John Paul II in our struggle against totalitarianism. Naturally, this is not a definite, let alone conclusive list, but we find these especially important:

Lesson 1: Compromises with Totalitarianism do not pay off very much in the long term

John Paul II displayed political savvy and "a shrewdness that combined steadiness of strategic vision with tactical flexibility" (Weigel 2018, 73). Nevertheless, as George Weigel put it, it seems that the Vatican's efforts to reach beneficial compromises with communist powers were rarely effective in the long term. It was rather deeply committed Christian pastors and laity who combined their piety with political shrewdness and steadfastness of the faith who outlasted the communist dictatorial rule as many times before, in history, the blood of martyrs proved to be the seed of victory. Their courageous sacrifices must never be forgotten. The best way to remember them is by imitating their example in our own life situations.

\section{Lesson 2: A Moral Revolution Must serve as the Basis for Social and Political Changes \\ Instead of a violent revolution, whether political or religious, the late Pope seems to leave us with a message of courage to engage in a moral revolution while guarding and actively cultivating the dignity of every human person, especially then the freedom of conscience as humankind's inalienable right (Petkovšek 2014). In his Encyclical Centesimus Annus from May 1991, John Paul II showed how any viable and just social order directly depends on recognizing human dignity and its}


transcendent source, and upon intentionally cultivating the person's moral responsibility:

It is by responding to the call of God contained in the being of things that man becomes aware of his transcendent dignity. Every individual must give this response, which constitutes the apex of his humanity, and no social mechanism or collective subject can substitute for it. The denial of God deprives the person of his foundation and consequently leads to a reorganization of the social order without reference to the person's dignity and responsibility (John Paul II 1991).

In fact, by emphasizing a moral revolution, John Paul II's message flew over the heads of Communist regimes, speaking directly to the oppressed people. "Let the Spirit descend and renew the face of the earth. This earth!" said the Pope during his first address as a Polish pope to gathering 2 million Poles in his homeland in June 1979. These words concluded a powerful homily preached by the Pope, in which John Paul II addressed his audience as a moral community of people who are to unite in their struggle for Christian values. The electrifying, mobilizing effect of these words could subsequently be felt throughout Poland. This rallying cry for personal integrity resulted in better working habits, more honesty and truth in interpersonal relationships, a new resolve to take responsibility for one's life, and new hope for a better future. Overall, people finally started to give up on their cynicism and lifted up their heads. This message of integrity and hope is very much relevant for people who continue living under oppressive regimes today, as well as for those surviving in the cynical atmosphere of the postmodern, consumerist societies.

Lesson 3: Importance of Philosophy (as a comprehensive, open, critical reflection that includes ethics and is open to Transcendence) in Times of Crises

If a 'moral revolution' is the way forward, how do we go about preparing for and facilitating such a moral revolution? How do we speak meaningfully and competently about values conducive to human fulfillment, happiness, and sustainable development today? (Ambrozy and Šagát 2019).

In his essay from 1979, The Person: Subject and Community, Wojtyła (1993, 219-220) argues that philosophy's essential function to question things and reflect critically has always been important for humankind; this task assumes new significance during the times of crises. At the turn of the 1970s, the Pope was convinced that the world was undergoing such a crisis. In Wojtyła's words, "The need for such understandings and justifications always accompanies humankind in its sojourn on earth, but this need becomes especially intense in certain moments of history, namely, in moments of great crisis and confrontation" (Wojtyła 1993, 220). He saw it as "imperative that the philosopher find a way to contribute in substantive ways to the concrete issues now faced by humankind" (Savage 2013, 19). John Paul II invites us to stop living as blind consumers or as always-complaining customers with a strong sense of entitlement instead of engaging in the painful yet liberating adventure of critical self-reflection. An unexamined life is not worth living, as Socrates would put it two and a half millennia ago. 


\section{Lesson 4: The Crucial Importance of a Competent Anthropology}

Our own critical self-reflection, as well as our penetrating assessment of the outside world, happens in the context of ideological battles and the fierce competition of worldviews. Anthropology finds itself at the very center of these battles of ideas, regardless of whether they are employed by ideologies or otherwise. John Paul II argued that our modern time is

...a time of great controversy about the human being, controversy about the very meaning of human existence, and thus about the nature and significance of the human being. This is not the first time that Christian philosophy has been faced with a materialistic interpretation, but it is the first time that such an interpretation has had so many means at its disposal and has expressed itself in so many currents (Wojtyła 1993, 220).

The truth about the human being is the foundation of any ensuing solutions for social living as well as individual decision making. When reflecting philosophically on the nature of the human being, the problem of the subjectivity of the human being as a person emerges at its core. Our being in the world, including human interpersonal interactions, morality, politics, and culture, revolves around this central issue, and if philosophy is to perform its necessary critical function, it must focus its attention on the issue of the subjectivity of human persons. ${ }^{5}$ John Paul II can thus be regarded as a personalist philosopher with a special emphasis on human subjectivity, particularly in relation to the human community in its historical situatedness. Wojtyła argues that the issue of the subjectivity of the human person "particularly in relation to the human community, imposes itself today as one of the central ideological issues that lie at the very basis of human praxis, morality (and thus also ethics), culture, civilization, and politics. Philosophy comes into play here in its essential function: philosophy as an expression of basic understandings and ultimate justifications" (Wojtyła 1993, 220). Yet, John Paul II does not invite us to some abstract philosophical deductions based on our most sophisticated theoretical ideas about the human person. Instead, he urges us to contemplate this mystery as we live and experience our human life. The lived human experience then remains the key to revealing the deep mysteries of human subjectivity.

Lesson 5: We must never give up the notion of Necessary Moral Context of the self-transcendent subject (subjective experience)

Wojtyła's emphasis on conceiving human beings as persons with a unique, unrepeatable experience of human subjectivity is always linked to a concrete moral context in which the self-transcendent subject experiences reality as a morally responsible subject. Wojtyła sees a metaphysical as well s methodological "priority of the personal subject in regard to the community. This means not only that people do exist and act together as a plurality of personal subjects, but also that we are not able to say anything essential about this coexistence and cooperation in the personalistic sense, that is, by way of community, if we do not begin with man precisely as a personal subject" (Wojtyła 1979b, 289). Thus, in this moral context of 
the self-transcendent subject, the subject (human person) has a priority over the community, though this is never in any isolationist, absolute sense. The meaning of Wojtyła's personalism "is largely practical and ethical: it is concerned with the person as a subject and an object of activity, as a subject of rights, etc." (Wojtyła 1993, 166). Therefore, any anthropological discourse must not stay blind to the fact that human beings are, constitutively, moral beings, and whatever they do or fail to do has a moral value.

Moreover, the irreducibility of the subjective is complemented by the concrete manifestations of the objective, physical world, not pitched against it. In his essay "Subjectivity and the Irreducible in the Human Being," Wojtyła (1993, 214) reminds us that

...the experience of the human being cannot be derived by way of cosmological reduction; we must pause at the irreducible, at that which is unique and unrepeatable in each human being, by virtue of which he or she is not just a particular human being - an individual of a certain species - but a personal subject. Only then do we get a true and complete picture of the human being. We cannot complete this picture through reduction alone; we also cannot remain within the framework of the irreducible alone (for then, we would be unable to get beyond the pure self.) The one must be cognitively supplemented with the other.

We must never forget that the movement of self-transcendence of the human subject exists at the core of one's lived experience within an objective moral context. "Wojtyła's effort to integrate the objective nature of human personhood and the subjective reality of the individual person is an essential element of his entire project" (Savage 2013, 21) and an important legacy of this personalist thought. As we struggle with various versions of excessive subjectivism and postmodern moral relativism, we ought to remember that his "account is a direct assault on those who would give more weight to subjective human experience over and against the possibility of universal moral norms and an objective moral order," as Deborah Savage rightly reminds us (Savage 2013, 21).

\section{Lesson 6: Natural Law ought to be Conceived of as a Lived Reality}

Wojtyła's conception of the significance of human lived experience brought him to the conclusion that the objectively existing natural law should not be conceived of as a logical philosophical inference, nor an abstraction based on theoretical analyses or empirical observations, but rather as something that moves our lives. Natural law can be accessed subjectively when it is lived when the human person experiences it as distinguishable instances of lived experience. In the Veritas Splendor Encyclical, pope John Paul II takes the challenge of the alleged historical contingency of the natural law and steers between the danger of abstracted fundamentalism on one side and the threat of relativism stemming from the historic-cultural conditioning of our understanding and implementation of the natural law. He acknowledges that humans "always [exist] in a particular culture, but it must also be admitted that [humans are] not exhaustively defined by that same culture" (John Paul II 1993). He then goes on to say that 
...the very progress of cultures demonstrates that there is something in man which transcends those cultures. This 'something' is precisely human nature: this nature is itself the measure of culture and the condition ensuring that man does not become the prisoner of any of his cultures but asserts his personal dignity by living in accordance with the profound truth of his being. To call into question, the permanent structural elements of man which are connected with his own bodily dimension would [...] conflict with common experience..." (John Paul II 1993).

The Pope is inviting us here to comprehend that the natural law "is written, not on the heart of an abstraction, or embedded in human nature only as a concept, however truthfully grasped, but on the hearts of concretely existing human persons who can and do experience it, irrespective of whether or not they attend to it adequately and authentically" (Savage 2013, 47). As Wojtyła says in his Acting Person, "It is impossible to detach the experiential ego from its ontological foundation," which is given by the Creator as a constitutive basis for conceiving the nature and intrinsic value of the human being (Wojtyła 1979a, 45).

Lesson 7: The Uniqueness and Dignity of every Human Person stem from the irreducibility and unrepeatability of his subjective, lived experience.

If Descartes started his system with 'Cogito ergo sum,' for Wojtyla, it would rather be 'I act therefore I am.' We must begin not with an imaginary human being but with a real, embodied human being who acts. Wojtyla agrees that there is a profound ability to create on the side of the human but qualifies it carefully. We formulate ourselves in connection with our father and mother and other subjects. There is a certitude of relationships. We need to look at ourselves from the perspective of other persons as they relate to us. One lives from inside (inside view) but also from outside with the help of others. It appears that Cartesianism (subjective, idealistic) and Thomism (objective) can be integrated here, according to John Paul II.

Therefore, each human being is this irreducible, personal experiencing subject living through his own actions and experiences. His lived experience is his personal way of being in the world and, as such, cannot be abstracted or reduced to any category (Aguas 2009, 429). The actual unrepeatability and uniqueness of every human person are derived precisely from the uniqueness of his subjective, lived experience, from his personal life-story. This was the case of Karol Wojtyła, too, as he openly testifies:

The two totalitarian systems which tragically marked our century Nazism, on the one hand, marked by the horrors of the war and the concentration camps, and communism on the other, with its regime of oppression and terror - I came to know, so to speak, from within. And so it is easy to understand my deep concern for the dignity of every human person and the need to respect human rights, beginning with the 
right to life. This concern was shaped in the first two years of my priesthood and has grown stronger with time. It is also easy to understand my concern for the family and young people" (Wojtyła 1996, 66-67).

Lesson 8: Only an Adequate Anthropology will serve as a foundation for a mature notion of human dignity and inalienable rights; Human rights have religious freedom at their center

We wish to refer here to George Weigel's City of Saints: a Pilgrimage to John Paul II's Kraków (2015), where he writes his thoughts summarizing the importance of a clear notion of human dignity and the human rights derived from a robust notion of dignity. Lifting up John Paul II's role in the Catholic' human rights revolution,' Weigel argues that it was "Pope John Paul II, the man who focused more than a century of Catholic social thought about the morally appropriate ways to organize modern political communities through the clarifying prism of basic human rights" who stood "at the center of the Catholic human rights revolution." He further claims that "at the center of John Paul II's defense and promotion of human rights was his insistence that religious freedom was the first of civil and political rights." This was, according to Weigel, yet another important "lesson the Polish pope brought from Krakow [i.e., from Cardinal Sapieha] to the world," (Weigel 2015, 136) a lesson we need to remember today. In his insistence on the primacy and irrefutability of the right to religious freedom, John Paul II built on the foundations of the Second Vatican Council. Shortly after his election as Pope, John Paul II gave an address to the United Nations General Assembly (1979). Religious freedom was at the center of his message. In it, the newly elected Pope argued that if we want to create limits to the power of the state and shelter human individuals from the state's capacity to encroach on the inner convictions, beliefs, and practiced rituals of individuals and communities, we must create a solid legal basis for religious freedom. Also important, we may add, will be to learn how to cherish and cultivate subjectively the notion of the indispensability of religious freedom for our human communal living (Bernačiak 2018; Jurko 2018).

\section{Lesson 9: A Mature Notion of Human freedom: Human Freedom is not Self- designed \\ Against the now popular hedonistic, relativistic, and libertarian trends in ethics and lifestyle, John Paul II (1993) in Veritatis Splendor states that the freedom that is intrinsic to every human person is known in the light of each person's dignity and, as such, is not self-designing.}

It is in the light of the dignity of the human person - a dignity which must be affirmed for its own sake - that reason grasps the specific moral value of certain goods towards which the person is naturally inclined. And since the human person cannot be reduced to a freedom which is self-designing, but entails a particular spiritual and bodily structure, the primordial moral requirement of loving and respecting the person as an end and never as a mere means also implies, 
by its very nature, respect for certain fundamental goods, without which one would fall into relativism and arbitrariness.

John Paul II's reference to "loving and respecting the person as an end and never as a mere means" constitutes the so-called 'personalist norm,' i.e., a fundamental trait of John Paul II's personalist outlook. ${ }^{6}$ Abiding by this 'norm' would arguably help create an environment fully conducive to healthy interpersonal and social relationships, more stable governments, and a more sustainable future of holistic human development on this planet.

\section{Lesson 10: We need authentic, believable living examples of faith and moral} integrity

Karol Wojtyła was "normal." He never behaved in a conceited manner even when his status might have qualified him to act in a dignified, reserved manner towards his subordinates and laity. While a priest in Kraków, groups of students regularly joined Wojtyła for hiking, skiing, bicycling, camping, and kayaking, accompanied by prayer, outdoor Masses, and theological discussions. In Stalinistera Poland, priests were not permitted to travel with groups of students, so he traveled incognito, and students called him 'wujek' (uncle). He did this to stay close to those he wished to understand deeply and serve unreservedly. Hence the task is the following: Let us be normal and care about people who are given to us in our circle of responsibility and influence, so in their lived experience, they can imitate the acts of selfless care and humble service that they see and experience in our lives.

\section{CONCLUSION}

John Paul II's legacy remains important for our efforts to fight old and new forms of totalitarianism today. His thoughts and actions inspired countless people in Poland and beyond during the decades of arguably the most difficult century of human history. The ten lessons that we have identified in this paper are but one of many examples (of studies) that who how his legacy may serve us today as we are confronted with new outbreaks of fascism, communism, hedonistic consumerism, nihilistic voluntarism, postmodern intellectual relativism, religious fundamentalism, and many other expressions of unfreedom and oppression in our contemporary world. Pope John Paul II lays in on our consciences to forsake violence (both political and religious) and instead plunge ourselves fully into the adventure of a moral revolution. However, such revolution can only be cultivated as a permanent movement of recognizing and upholding the inalienable dignity of every human being as irreducible human subjects, as persons with their unique lived experience (Truong 2019) irreducible and unrepeatable life narratives.

We argue that our struggle with old and new forms of totalitarianism today takes place through the perils of one's personal 'moral revolution.' A new world order of peace and justice is only conceivable when built on an authentic conception of the human being as a person with inalienable dignity and a society that respects 
human rights, beginning with the right to religious freedom and freedom of conscience. As a unity of finite and infinite, the human being is an individual, a beautiful, self-aware, creative, reflecting, and self-reflecting, and yet contingent human subject that stands before God (Kardis 2019) as the source and ultimate goal of his/her existence. "This reflective freedom, actualized in concrete attitudes and actions within complex social relationships, experiencing passion and anxiety, love and doubt, fear and ecstasy - this dynamic tension between autonomy and contingency, the immediate and that which transcends her - is a good basis for the kind of existential, moral revolution we are hoping for" (Valčo 2015b, 137). With his clear way of reasoning and convincing life story, John Paul II continues to be a valuable resource in an age of increased fragmentation and uncertainty (epistemological, moral, existential, etc.). The Pope reminds the world that human individuals are "substantial, personal beings, constituted as free and responsible agents (Kralik 2013,39) meant to live in creative and altruistic relations with others."

The dignity of all human persons "is inalienable and indisputable precisely because their human selves have a transcendent source and eternal destiny (in their necessary albeit often unrecognized relatedness to God) because the Transcendent is their ground of existence as well as their ultimate concern" (Valčo 2015b, 137). Moreover, the uniqueness and dignity of every human person stem from the irreducibility and unrepeatability of their subjective, lived experience, their personal life-story that is interwoven into the drama of this world. John Paul II's ability to interweave the aspect of acute immanence of human self-awareness (subjectivity) and self-transcendence (Klun 2017), with the objective world as a necessary moral context of human lived experience, and with the reality of transcendence (Žalec 2019) - as both, the anchor and goal of a person's existence - carries a great potential for contemporary philosophical, religious, and social-ethical discourse. ${ }^{7}$

\section{Acknowledgment:}

This paper was supported by the Polish Institute of Advanced Studies in Warsaw (PIASt), the Polish Academy of Sciences, where the first author holds the position of "Senior research fellow."

\section{NOTES}

1. A more complex description of the situation in Czechoslovakia between 19481989 was published by Michal Valčo (2016, 116-119).

2. Recent collectivist and etatistic solutions have not worked and will not work. Here we refer to the socialists' attempts at creating cohesive communities based on common ownership and the state-caused disappearance of exploitation perpetrated by private business owners, as well as to many failed attempts by the European national governments to impose a new 'vision' of communal life and individual altruism by new laws and regulations. See Georg Schöpflin's (1990) provocative study on this subject. It is not viable to 'impose' a higher sense of cohesiveness or a stronger determination to selflessness and altruism by any type of governmental social engineering. However, European governments tend to do just that. 
3. In his Sources of the Self, Charles Taylor (1989) was right to point out that we, people in the Western world of modernity, are "living beyond our moral means." He states provokingly: "The question which arises from all this is whether we are not living beyond our moral means in continuing allegiance to our standards of justice and benevolence. Do we have ways of seeing-good which are still credible to us, which are powerful enough to sustain these standards?" (Taylor 1989, 517).

4. In September 1980, Polish Solidarnosc became the first independent labor union in a country belonging to the Soviet bloc. This trade/labor union has become a wider social movement of solidarity with those workers and their families who have been persecuted or disadvantaged by the Polish communist regime. It is revealing to notice that Lech Walesa, the leader of Solidarity and later president of Poland (19901995), signed the accords ending nation-wide strikes in Poland with a pen bearing John Paul II's picture.

5. Wojtyla thinks of a relative, limited subjectivity of the human as opposed to the absolute subjectivity of God. The subject must be placed in the essence to see that a subject is also an object at the same time. The subject must not be reduced to an object, but excessive subjectivism is also bad because it fails to see the object. Abstract category of subjectivity does not correspond to our lived reality.

6. Pope John Paul II, much like his predecessor, Pope John XXIII, strived to apply this 'personalist norm' to all people, including his opponents. While hating communism as an evil ideology, John Paul II cared deeply about the individual members of the communist party and their families.

7. John Paul II's emphases on this subject resemble some of the key ideas of the religious existentialists, namely Soren A. Kierkegaard and Dietrich Bonhoeffer. See: (Valčo 2015b; Binetti and Pavlikova 2019). Aguas, too, notices John Paul II's affinity to existential thinkers. Commenting on 'lived experience,' Aguas states: "Lived experience, on the other hand, is a category introduced by the existentialists and phenomenologists, to emphasize the fact that experience is not just an epistemological category but an anthropological category that is essential in interpreting the subjectivity of the human person" (Aguas 2009, 429).

\section{REFERENCES}

Aguas, Jove Jim. 2009. Karol Wojtyla: On person and subjectivity. Ad Veritatem 8 (2): 413-453.

Aikman, David. 2003. Great Souls: Sic who changed a century. Lanham MD: Lexington Books.

Ambrozy, Marian and Peter Šagát. 2019. Axiological aspect in the context of teaching philosophy. XLinguae 12(3): 218-227.

Bernačiak, Juraj. 2018. Dôstojnost' človeka, ako subjektu, pre realizáciu spravodlivosti a lásky, vo svetle vyjadrení niektorých teológov a sociológov v XX. storočí a na začiatku XXI. Storočia. Theologos XX(1): 25-51.

Binetti, Maria J. and Martina Pavlikova. 2019. Kierkegaard on the reconciliation of conscience. XLinguae 12(3): 192-200. 
Böckenförde Ernst-Wolfgang. 1991. The Rise of the State as a Process of Secularisation. In: Ernst-Wolfgang Böckenförde, State, Society and Liberty. Studies in Political Theory and Constitutional Law. New York - London: Berg Publ. Ltd., p. 26-46.

Giddens, Anthony. 1998. The Third Way. The Renewal of Social Democracy. Cambridge: Polity Press.

Harvey, David. 2010. The Enigma of Capital. New York: Oxford University Press.

Hinlicky, Paul. 2010. Luther and the Beloved Community: A Path for Christian Theology After Christendom. Grand Rapids: Eerdmans Publishing.

Hinlicky, Paul. 2016. Between Humanist Philosophy and Apocalyptic Theology: The Twentieth Century Sojourn of Samuel Stefan Osuský. London - New York: T\&T Clark.

Hudek, Adam. 2013. Twenty years wasted? Constructing a Narrative of 1989 in Slovakia. In Overcoming the Old Borders. Beyond the Paradigm of Slovak National History. Bratislava: Historický ústav SAV, p. 167-178.

John Paul II. 1991. Encyclical Letter 'Centesimus Annus' (May 1, 1991) [online]. Available at: http://www.vatican.va/content/john-paulii/en/encyclicals/documents/hf_jp-ii_enc_01051991_centesimus-annus.html (cit. 10 Jan 2020).

. 1993. Encyclical Letter 'Veritatis Splendor' (August 6, 1993) [online]. Available at: http://www.vatican.va/content/john-paulii/en/encyclicals/documents/hf_jp-ii_enc_06081993_veritatis-splendor.html (cit. 10 Feb 2020).

Jozefčiaková, Silvia (ed.). 2004. Štát a cirkev v postsocialistickej Európe II. Bratislava: Prešov: Ústav pre vzt'ahy štátu a cirkví.

Jurko, Jozef. 2018. Sloboda v duchu Druhého vatikánskeho koncilu. Theologos $\mathrm{XX}(1): 52-63$.

Kardis, Mária, Šturák, Peter, Králik, Roman, Nguyen Trong, Daniela, Korzhuev, Andrey V., Kryukova, Nina I. 2019. A sociological-religious probe into contemporary global Salafi jihadism. European Journal of Science and Theology. 15 (4): 113-125.

Kardis, Mária and Kardis, Kamil. 2019. Religia a wartości na tle tożsamości kultury polskiej i litewskiej. Analiza socjologiczno - historyczna w oparciu o nauczanie kardynała Stefana Wyszyńskiego. Historia Ecclesiastica: časopis pre dejiny cirkví a náboženstiev v Strednej Európe 10 (1): 149-175.

Kardis, Mária. 2019. The Presence of God - Certainty or Uncertainty? Religious Experience in the Biblical Tradition. Theologos XXI(1): 121-129.

Klun, Branko. 2017. Transcendenca, samo-transcendenca in časovnost: fenomenološki razmisleki [Transcendence, Self-Transcendence, and Temporality: Some Phenomenological Reflexions]. Bogoslovni vestnik 77(3/4): 503-516.

Konstantinov, Fiodor V. 1973. Základy marxisticko-leninskej filozofie, Bratislava: Pavda.

Králik, Roman. 2013. Kierkegaardi̊v Abrahám: Kierkegaardova interpretace Abrahámovy víry. Ljubljana: KUD Apokalipsa. 
Králik, Roman and Susanne J. Tinley. 2017. Kierkegaard's ethics as an answer to human alienation in technocratic society. Communications - Scientific Letters of the University of Zilina 19(1) 25-29.

Letz, Robert. 2007. Dokumenty $k$ procesu $s$ katolíckymi biskupmi Janom Vojtaššákom, Michalom Buzalkom a Pavlom Gojdičom. Bratislava: UPN

MacIntyre, Alisdair. 1984. Marxism and Christianity. Notre Dame: University of Notre Dame Press.

Magdolen, Jozef. 2015. Politological Characteristic of the Slovak Sate in the period of 1938-1945. In Michael McGreevy and Robert Rita (Editors), CER Comparative European Research 2015. London: Sciemcee Publishing, p. 232238.

Mannová, Elena (ed). 2003: Krátke dejiny Slovenska, Bratislava: Historický ústav Slovenskej akadémie vied.

Markwick, Roger D. 2002. Stalinism at War. Kritika: Explorations in Russian and Eurasian History 3(3): 509-520.

Martin, Jose Garcia, Arturo Morales Rojas, and Roman Kralik. 2020. The problem of the 'individual' concept in the Kierkegaard's journals. European Journal of Science and Theology 16(2): 39-46.

Marx, Karl. 2000. Introduction to A Contribution to the Critique of Hegel's Philosophy of Right. In Deutsch-Französische Jahrbücher, February, 1844 [online], Marx/Engels Internet Archive (marxists.org). Available at: http://www.marxists.org/archive/marx/works/1843/critique-hpr/intro.htm (cit. 25 Jan 2020).

Muzykant, Valerii L., Elena B. Ponomarenko, Victor V. Barabash, Vladimir N. Denisenko, and Olga V. Shlykova. 2019. New media: invective language transformation of global communication. XLinguae 12(1): 80-90.

Petkovšek, Robert. 2014. Nasilje in etika kriza v luci eksistencialne analitike in mimeticne teorije. Bogoslovni vestnik 74(4): 575-592.

Piry, Martin. 2019. Katolícke sociálne učenie v konfrontácii s liberálnou demokraciou. In Michal Klučiarovský and Tomáš Zajac (eds.), Demokracia v 21. storoči. Konferencia o výzvach a limitoch liberálnej demokracie a zákonitých etapách jej vývoja. Bratislava: Central European Education Institute.

Pope Paul VI. 1965. Dignitatis Humanae. Declaration on Religious Freedom [online]. Rome: II Vatican Council. Available at: http://www.vatican.va/archive/hist_councils/ii_vatican_council/documents/vatii_decl_19651207_dignitatis-humanae_en.html (cit. 12 Jan 2020).

Savage, Deborah. 2013. The Centrality of Lived Experience in Wojtyla's Account of the Person. Roczniki filozoficzne 61(4): 19-51.

Schöpflin, Georg. 1990. The political traditions of Eastern Europe. Daedalus 119(1): 55-90.

Solidarity, Pope John Paul II, and the Orange Alternative: Bringing Down Communism in Poland [online]. Tavaana Portal. Available at: https://tavaana.org/en/en/content/solidarity-pope-john-paul-ii-and-orangealternative-bringing-down-communism-poland-0 (cit. 8 Feb 2020). 
Tavilla, Igor, Roman Kralik, Carson Webb, Xiamgdong Jiang, and Juan Manuel Aguilar. 2019. The rise of fascism and the reformation of Hegel's dialectic into Italian neo-idealist philosophy. XLinguae 12(1): 139-150.

Taylor, Charles. 1989. Sources of the Self: The Making of the Modern Identity. Cambridge, MA: Harvard University Press.

Tierney, John J. 2017. Conceived in Liberty: The American Worldview in Theory and Practice. Routledge.

Tismaneanu, Vladimir. 2009. Postcommunism between hope and disenchantment. Journal of International Relations and Development 12(4): 354-364.

Touraine, Alain. 2001. Beyond Neoliberalism, London: Polity Press.

Truong, Thi Thanh Qui. 2019. The Importance of Personality in the Context of Human Education: Global Experience and Vietnamese Philosophical Perspectives. XLinguae 12(4): 192-211.

Valčo, Michal. 2012. Setting the stage for a meaningful engagement: The need for a competent public theology in the post-communist context of Slovakia. In Michal Valčo and Daniel Slivka (eds.), Christian churches in post-communist Slovakia: current challenges and opportunities. Salem, VA: Center for religion and society, Roanoke college, p. 185-258.

Valčo, Michal. 2013. Communism as a Christian heresy: a false (and failed) prophecy of an ideology. In Zdeněk David (ed.), SVU and its role in the era of globalisation: transatlantic collaboration, innovation and preservation. Proceedings from the 26th SVU world congress of the Czechoslovak society of arts and sciences July 1-6, 2012 in Žilina, Slovakia. Highland Part, NJ.: Czechoslovak Society of Arts and Sciences, p. 289-309.

Valčo, Michal. 2015a. The Role of the Church in a Post-narratable World: Bringing Meaning to Reality through a Credible Narrative. In Lubomír M. Ondrášek and Ivan Mod'oroši (eds.), Church and society: towards responsible engagement. Ružomberok: VERBUM, p. 270-284.

Valčo, Michal. 2015b. Rethinking the role of Kierkegaard's 'authentic individual' in liberal capitalist democracies today. European journal of science and theology 11(5): 129-139.

Valčo, Michal. 2016. Religion, political tyranny, and the power of narrative: a case study of Slovakia (1939-1960) with implications for the present. In Janez Juhant and Bojan Žalec (eds.), Which religion, what ideology? The (religious) potentials for peace and violence. LIT Verlag: Zürich, p. 115-124.

Vasil'ková, Adriana and Jarmila Androvičová. 2018. Historical Development and Current Forms of Political Radicalism and Extremism in Slovakia. Current Politics \& Economics of Europe 29(1): 47-82.

Veith, Gene E. Jr. 1993. Modern Fascism: Liquidating the Judeo-Christian Worldview. St. Louis: Concordia Publishing House.

Wacquant, Loïc, and Laurance Roulleau-Berger. 2003. Labour market insecurity and the criminalization of poverty. In Laurence Roulleau-Berger (ed.), Youth and Work in The Post-Industrial City of North America and Europe. Leiden Boston: Brill, p. 408-19.

Weigel, George. 2015. City of Saints: A pilgrimage to John Paul II's Kraków. New York: Image Publishing. 
Weigel, George. 2018. The fragility of order: Catholic reflections on turbulent times. Ignatius Press.

Wojtyla, Karol. 1979a. The Acting Person: A Contribution to Phenomenological Anthropology. Springer, Netherlands.

Wojtyla, Karol. 1979b. The Person: Subject and Community. The Review of Metaphysics 33(2) 273-308.

Wojtyla, Karol. 1993. Person and Community. New York: Peter Lang.

Wojtyla, Karol. 1996. Gift and Mystery: On the Fiftieth Anniversary of My Priestly Ordination. New York: Bantam Doubleday Dell Audio.

Žalec, Bojan. 2019. Between Secularity and Post-Secularity: Critical Appraisal of Charles Taylor's Account. Bogoslovni Vestnik 79(2): 411-423.

Žalec, Bojan. 2013. Globinski izvor genocida in totalitarizma v Kierkegaardovih pojmih tesnobe in stadijev eksistence: zgled nacizma in stalinizma. Bogoslovni vestnik 73(3): 349-356. 